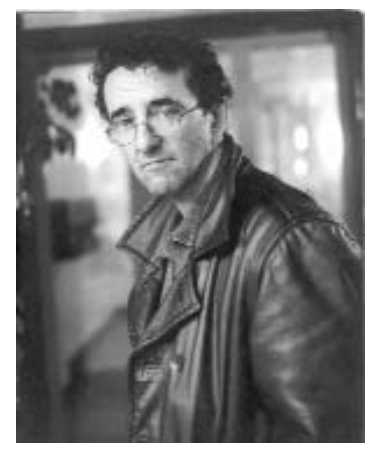

\title{
2666 \\ Roberto Bolaño
}

Editorial Anagrama

La relación con el poder de los intelectuales mexicanos viene de lejos. No digo que todos sean así. Hay excepciones notables. Tampoco digo que los que se entregan lo hagan de mala fe. $\mathrm{Ni}$ siquiera que esa entrega sea una entrega en toda regla. Digamos que sólo es un empleo. Pero es un empleo con el Estado. En Europa los intelectuales trabajan en editoriales o en la prensa o los mantienen sus mujeres o sus padres tiene buena posición y les dan una mensualidad o son obreros y delincuentes y viven honestamente de sus trabajos. En México, y puede que el ejemplo sea extensible a toda Latinoamérica, salvo Argentina, los intelectuales trabajan para el Estado. Esto era así con el PRI y sigue siendo así con el PAN. El intelectual, por su parte, puede ser un fervoroso defensor del Estado o un crítico del Estado. Al Estado no le importa. El Estado lo alimenta y lo observa en silencio. Con su enorme cohorte de escritores más bien inútiles, el estado hace algo. ¿¿Qué? Exorciza demonios, cambia o al menos intenta influir en el tiempo mexicano. Añade capas de cal a un hoyo que nadie sabe si existe o no existe. Por supuesto, esto no siempre es así. Un intelectual puede trabajar en la universidad o, mejor, irse a trabajar a una universidad norteamericana, cuyos departamentos de literatura son tan malos como los de las universidades mexicanas, pero esto no lo pone a salvo de recibir una llamada telefónica a altas horas de la noche y que alguien que habla en nombre del Estado le ofrezca un trabajo mejor, un empleo mejor remunerado, algo que el intelectual cree que se merece, y los intelectuales siempre creen que se merecen algo más. Esta mecáni$\mathrm{ca}$, de alguna manera, desoreja a los escritores mexicanos. Los vuelve locos. Algunos, por ejemplo, se ponen a traducir poesía japonesa sin saber japonés y otros, ya de plano, se dedican a la bebida. Almendro, sin ir más lejos, creo que hace ambas cosas. La literatura en México es como un jardín de infancia, una guardería, un kindergarten, un parvulario, no sé si lo podéis entender. El clima es bueno, hace sol, uno puede salir de casa y sentarse en un parque y abrir un libro de Valéry, tal vez el escritor más leído por los escritores mexicanos, y luego acercarse a casa de los amigos y hablar. Tu sombra, sin embargo, ya no te sigue. En algún momento te ha abandonado silenciosamente. Tú 
haces como que no te das cuenta, pero sí que te has dado cuenta, tu jodida sombra ya no va contigo, pero, bueno, eso puede explicarse de muchas formas, la posición del sol, el grado de inconsciencia que el sol provoca en las cabezas sin sombrero, la cantidad de alcohol ingerida, el movimiento como de tanques subterráneos del dolor, el miedo a cosas más contingentes, una enfermedad que se insinúa, la vanidad herida, el deseo de ser puntual al menos una vez en la vida. Lo cierto es que tu sombra se pierde y tú, momentáneamente, la olvidas. Y así llegas, sin sombra, a una especie de escenario y te pones a traducir o a reinterpretar o a cantar la realidad. El escenario propiamente dicho es un proscenio y al fondo del proscenio hay un tubo enorme, algo así como una mina o la entrada a una mina de proporciones gigantes. Digamos que es una caverna. Pero también podemos decir que es una mina. De la boca de la mina salen ruidos ininteligibles. Onomatopeyas, fonemas furibundos o seductores o seductoramente furibundos o bien puede que sólo murmullos y susurros y gemidos. Lo cierto es que nadie ve, lo que se dice ver, la entrada de la mina. Una máquina, un juego de luces y de sombras, una manipulación en el tiempo, hurta el verdadero contorno de la boca a la mirada de los espectadores. En realidad, sólo los espectadores que están más cercanos al proscenio, pegados al foso de la orquesta, pueden ver, tras la tupida red de camuflaje, el contorno de algo, no el verdadero contorno, pero sí, al menos, el contorno de algo. Los otros espectadores no ven nada más allá del proscenio y se podría decir que tampoco les interesa ver nada. Por su parte, los intelectuales sin sombra están siempre de espaldas y por lo tanto, a menos que tuvieran ojos en la nuca, les es imposible ver nada. Ellos sólo escuchan los ruidos que salen del fondo de la mina. Y los traducen o reinterpretan o recrean. Su trabajo, cae por su peso decirlo, es pobrísimo. Emplean la retórica allí donde se intuye un huracán, tratan de ser elocuentes allí donde intuyen la furia desatada, procuran ceñirse a la disciplina de la métrica allí donde sólo queda un silencio ensordecedor e inútil. Dicen pío pío, guau guau, miau miau, porque son incapaces de imaginar un animal de proporciones colosales o la ausencia de ese animal. El escenario en el que trabajan, por otra parte, es muy bonito, muy bien pensado, muy coqueto, pero sus dimensiones con el paso del tiempo son cada vez menores. Este achicamiento del escenario no lo desvirtúa en modo alguno. Simplemente cada vez es más chico y también las plateas son más chicas y los espectadores, naturalmente, son cada vez menos. Junto a este escenario, por supuesto, hay otros escenarios. Escenarios nuevos que han crecido con el paso del tiempo. Está el escenario de la pintura, que es enorme, y cuyos espectadores son pocos pero todos, por decirlo de algún modo, son elegantes. Está el escenario del cine y de la televisión. Aquí el afo- 
ro es enorme y siempre está lleno y el proscenio crece a buen ritmo año tras año. En ocasiones, los intérpretes del escenario de los intelectuales se pasan, como actores invitados, al escenario de la televisión. En este escenario la boca de la mina es la misma, con un ligerísimo cambio de perspectiva, aunque tal vez el camuflaje sea más denso y, paradójicamente, esté preñado de un humor misterioso y que sin embargo apesta. Este camuflaje humorístico, naturalmente, se presta a muchas interpretaciones, que finalmente siempre se reducen, para mayor facilidad del público o del ojo colectivo del público, a dos. En ocasiones los intelectuales se instalan para siempre en el proscenio televisivo. De la boca de la mina siguen saliendo rugidos y los intelectuales los siguen malinterpretando. En realidad, ellos, que en teoría son los amos del lenguaje, ni siquiera son capaces de enriquecerlo. Sus mejores palabras son palabras prestadas que oyen decir a los espectadores de primera fila. A estos espectadores se les suele llamar flagelante. Están enfermos y cada cierto tiempo inventan palabras atroces y su índice de mortalidad es elevado. Cuando acaban la jornada laboral se cierran los teatros y se tapan las bocas de las minas con grandes planchas de acero. Los intelectuales se retiran. La luna es gorda y el aire nocturno es de una pureza tal que parece alimenticio. En algunos locales se oyen canciones cuyas notas llegan a las calles. A veces un intelectual se desvía y penetra en uno de estos locales y bebe mezcal. Piensa entonces qué sucedería si un día él. Pero no. No piensa nada. Sólo bebe y canta. A veces alguno cree ver a un escritor alemán legendario. En realidad sólo ha visto una sombra, en ocasiones sólo ha visto a su propia sombra que regresa a casa cada noche para evitar que el intelectual reviente o se cuelgue del portal. Pero él jura que ha visto a un escritor alemán y en esa convicción cifra su propia felicidad, su orden, su vértigo, su sentido de la parranda. A la mañana siguiente hace un buen día. El sol chisporretea, pero no quema. Uno puede salir de casa razonablemente tranquilo, arrastrando su sombra, y detenerse en un parque y leer unas páginas de Valéry. Y así hasta el fin.

- No entiendo nada de lo que has dicho- dijo Norton.

- En realidad sólo he dicho tonterías- dijo Amalfitano. 